\title{
MINERALOGICAL, PETROGRAPHIC AND STABLE ISOTOPIC STUDY OF ANCIENT WHITE MARBLE QUARRIES IN THESSALY, GREECE - II. CHASANBALI, TEMPI, ATRAX, TISAION MOUNTAIN
}

\author{
Melfos V. ${ }^{1}$, Voudouris P. ${ }^{2}$, Papadopoulou L. ${ }^{1}$, Sdrolia S. ${ }^{3}$ and Helly B. ${ }^{4}$ \\ ${ }^{1}$ Department of Mineralogy, Petrology, Economic Geology, School of Geology, Aristotle University \\ of Thessaloniki, 54124, Thessaloniki, Greece,melfosv@geo.auth.gr \\ ${ }^{2}$ Department of Mineralogy-Petrology, School of Geology and Geoenvironment, University of Athens, \\ 15784, Athens, Greece \\ ${ }^{3} 7$ th Ephorate of Byzantine Antiquities, 46 Anthimou Gazi Str., 41222 Larissa, Greece \\ ${ }^{4}$ Institut Fernand-Courby (UMR 5649 du CNRS), Maison de I'Orient, 7 rue Raulin, F-69007, Lyon, France
}

\begin{abstract}
The present study focuses on the identification of marble sources from four ancient quarries in Thessaly, including Atrax, Tempi, Chasanbali and Tisaion and aims in characterizing the variations of the mineralogical and petrographic features, and the stable isotope ratios $\left(\delta^{13} \mathrm{C}\right.$ and $\left.\delta^{18} \mathrm{O}\right)$. The results provide additional data and complete the databases presented in previous works from Kastri, Kalochorion and Gonnoi. Microscopy was employed both to evidence the geometrical relationships among the mineral constituents, with particular reference to calcite, and to detect the accessory grains. The studied marbles demonstrate various textures, whereas the maximum grain size of calcites has been used to discriminate the marbles. The geometric relationships of carbonate grains, such as the grain boundary shape, were also evaluated. According to the stable isotope compositions, most of the samples plot in the same area, although some groupings are observed.
\end{abstract}

Key words: white marble, ancient quarries, ancient technology, mineralogy, marble textures, $C$ and $O$-isotopes, Thessaly, Central Greece.

\section{Introduction}

Identifying ancient marbles is of great importance to archaeologists and art historians. Provenance studies provide useful archaeological information regarding contacts, trade and other activities during antiquity. They also help in detection of modern imitations or ancient copies of original works. In addition, location of the quarry from which a damaged marble artefact came, makes it possible to find proper material for the purpose of restorations, reconstructions and replacements (Lazzarini, 2004; Tycot, 2004).

Since many of the marble sources that were exploited in antiquity are of white marble, it is not easy to distinguish among most of them based only on their macroscopical and morphological features, as large variations of the physical properties can be observed even for marbles from the same quarry or quarrying area.

The application of various analytical methods allow many sources to be positively identified (Craig 
and Craig, 1972; Coleman and Walker, 1979; Lazzarini et al., 1980; Herz, 1987; Mello et al., 1988; Moens et al., 1988; Tsirambides, 1996; Vakoulis, 2000; Attanasio et al., 2003; Capedri et al., 2004; Melfos, 2004; Perugini et al., 2004). In particular, only one method is not enough for recognizing marbles, and so the most recent and effective approaches usually combine different techniques, such as mineralogical composition, petrographic analysis, stable isotopes $\left({ }^{13} \mathrm{C}\right.$ and $\left.{ }^{18} \mathrm{O}\right)$ and trace element analysis. Other physical or geochemical methods have been applied in recent years with some success. Examples include the use of thermoluminescence, strontium isotopic distribution, manganese electron spin or paramagnetic resonance (ESR-FPR), porosity, heat capacity, back-scattering or diffusion of light, gamma-ray radiography, dimensional or other geometrical data obtained from thin-sections examination with automatic quantitative image analysis.

The most widely used and accurate procedure for the identification of white marbles involves mineralogical and petrographic studies in combination with $\mathrm{C}-\mathrm{O}$ stable isotope analyses. According to Gorgoni et al. (2002), this progressive implementation is based on two procedures: i) creating sets of reference data for new marble supply areas of known or potential archaeological interest never previously considered and ii) improving and detailing the database for the most important marbles of antiquity.

The large overlapping of the isotopic data fields from different localities renders $\delta^{13} \mathrm{C}-\delta^{18} \mathrm{O}$ plots often ineffective in discriminating the marble sources. It is therefore evident that additional methods should be applied for a more specific determination of the provenance. Mineralogical composition and petrographic studies could help in distinguishing the different sources (Capedri et al., 2004).

Thessaly in Central Greece demonstrates an impressive history throughout the centuries, since the Neolithic period. It must have played a key economic role in the antique Aegean, and indeed Mediterranean, world. The economy of the region was based on the exploitation of local resources and trade. Among the local resources particular emphasis is placed on the exploitation of the local white marble quarries (Karagiorgou, 2001).

The importance of Thessalian marbles implies that their correct provenancing, as well as the possibility of identifying specific quarrying areas, are both crucial archaeological issues and may provide important information on the economy and art history of classical antiquity. However, only limited studies have been published so far on the quarries and the marbles of Thessaly, by Papageorgakis (1967), Germann et al. (1980), Melfos et al. (2002) and Melfos (2004, 2008). These authors have also published databases on the Thessalian white marbles based on isotopes, but also on alternative techniques, such as mineralogy and petrography.

When identifying ancient marble artefacts by means of petrographic and isotopic methods, sometimes the results do not match well with the sets of comparative parameters for the various supply areas. These discrepancies are possibly due to incompleteness or limited reliability of the databases available.

The present study focuses on four white marble quarries in Thessaly county (Fig. 1) and aims in characterizing the variations of the mineralogical and petrographic features, as well as the stable isotope ratios $\left({ }^{13} \mathrm{C}\right.$ and $\left.{ }^{18} \mathrm{O}\right)$. These quarries are located in Chasanbali (Sykourio area), in Tempi, in ancient Atrax (between Larisa and Trikala) and on Tisaion Mountain in Magnesia (Fig. 1). The results of this study provide additional data and complete the databases presented in a previous work by Melfos (2004), which included the ancient quarries in the Kastri village (Aghia area), in Kalochorion (Sykourio area) and in ancient Gonnoi (Tempi area) (Fig. 1). 


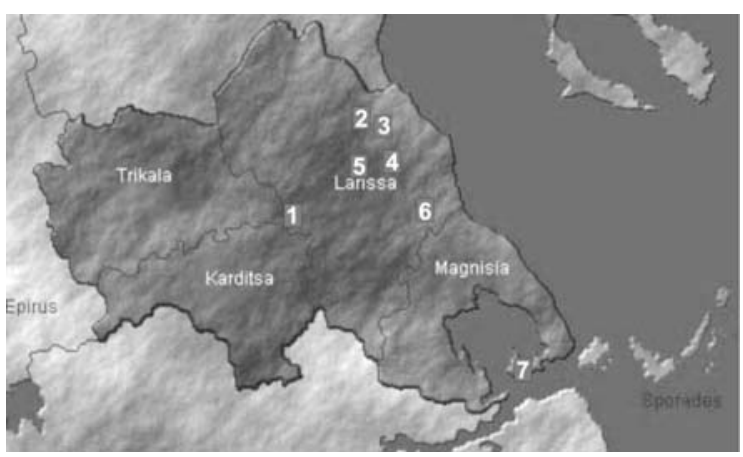

Fig. 1: Map of Thessaly in central Greece, showing the locations of ancient whitemarble quarries. 1. Ancient Atrax, 2. Ancient Gonnoi, 3. Tempi, 4. Chasanbali, 5. Kalochori, 6. Kastri, 7. Tisaion mountain.

\section{Geological setting}

The area of Thessaly belongs geotectonically in the Pelagonian zone, which is composed of several tectonic units, showing different tectono-metamorphic evolution. It is considered as a microcontinent that rifted from Apulia during Permo-Triassic, giving rise to two small ocean basins, the Pindos ocean in the west and the Axios-Vardar ocean in the east (Robertson et al., 1991). After the continental collision in Early Tertiary, these small ocean basins closed.

The pre-Alpine crystalline basement consists of granites, ortho- and para-gneisses of Late Proterozoic to Palaeozoic ages (Kilias and Mountrakis, 1989; Koroneos et al., 1993; Anders et al., 2007).

The basement is structurally overlain by the composite Pelagonian nappe consisting of a basal tectonic mélange, exposed in northern Euvoia and in Koziakas (Danelian and Robertson, 2001; Pomonis et al., 2007), including Triassic metavolcanic series (metarhyolites, amphibolites, mica-schists, greenschists) and Triassic-Jurassic deep-water metasedimentary rocks (mainly schists, prasinites, amphibolites, marbles and dolomitic marbles).

These series were overthrusted during Early Cretaceous by the Axios-Vardar ophiolite complexes of ultramafic and mafic rocks found mainly in Eastern Thessaly and Northern Euvoia, the easternmost parts of the Pelagonian zone (Danelian and Robertson, 2001). They show important Early Cretaceous weathering and are unconformably overlain by Mesozoic to recent sediments, including transgressive Late Cretaceous meso-autochthonous shallow-water crystalline limestones that pass upwards into Palaeocene flysch (Katsikatsos et al., 1981; Caputo, 1990).

\section{Analytical Methods}

A total of 25 samples of fresh white marble were collected from the studied ancient quarries in Chasanbali, Tempi, Atrax and Tisaion mountain, for mineralogical, petrographic and isotopic analyses, during fieldwork between 2005 and 2009. A total of 14 thin and polished-thin sections of the rock samples were studied mineralogically by optical microscopy at the Department of Mineralogy, Petrology, Economic Geology, Aristotle University of Thessaloniki, Greece. Microscopy was employed both to evidence the geometrical relationships among the mineral constituents, with particular reference to calcite, as well as to detect the accessory grains. The studied marbles demonstrate various textures such as homeoblastic or heteroblastic marbles. The maximum grain size of calcite (MGS), which has been used to discriminate the marbles, was measured. The geometric relationships of carbonate grains, such as the grain boundary shape, were also evaluated under the microscope. These features depend on the metamorphic evolution. 
In addition, powders of the samples were processed by X-ray diffraction (XRD) in order to distinguish calcite from dolomite and to verify the related abundances in each sample. Oxygen and carbon isotopic analyses of 16 marble samples were carried out at the Department of Geology of Royal Holloway, University of London. The oxygen and carbon isotope ratios are referred to the standard VDPB (Belemnitella americana from the Cretaceous Pee Dee Formation, South Carolina). The colour and macroscopical characteristics, the mineralogical composition, the textural features, MGS, and a general description of the analysed marbles are depicted in Table 1, which reports also $\mathrm{O}$ and $\mathrm{C}$ isotopes composition.

Table 1. Macroscopic characteristics, mineralogical composition, textures and isotopic compositions of the marbles in studied ancient quarries of Thessaly.

\begin{tabular}{|c|c|c|c|c|c|c|c|}
\hline Locality & Sample & $\begin{array}{c}\text { Macroscopic } \\
\text { characteristics }\end{array}$ & $\begin{array}{l}\text { Mineralogical } \\
\text { composition }\end{array}$ & Texture & $\begin{array}{c}\text { Shape of } \\
\text { the crystal } \\
\text { boarders }\end{array}$ & MGS* & C-O isotopes \\
\hline \multirow{2}{*}{ Atrax } & $\begin{array}{l}\text { Atr } 1 \\
\text { Atr } 2\end{array}$ & $\begin{array}{c}\text { Coarse-grained. } \\
\text { White to grayish } \\
\text { white colour }\end{array}$ & $\begin{array}{c}\text { calcite, apatite, } \\
\text { sulfides, } \\
\text { Fe-oxides }\end{array}$ & $\begin{array}{c}\text { Homeoblastic } \\
\text { to slightly het- } \\
\text { eroblastic }\end{array}$ & $\begin{array}{l}\text { Sutured } \\
\text { dentate, } \\
\text { embayed }\end{array}$ & $4 \mathrm{~mm}$ & $\begin{array}{c}\delta^{18} \mathrm{O}:-1.77--3.36 \% \\
\delta^{13} \mathrm{C}: 1.65-2.27 \%\end{array}$ \\
\hline & Atr 3 & $\begin{array}{c}\text { Fine-grained. } \\
\text { White colour } \\
\text { with pinkish tint }\end{array}$ & $\begin{array}{c}\text { calcite, apatite, } \\
\text { sulfides, } \\
\text { Fe-oxides }\end{array}$ & Heteroblastic & $\begin{array}{l}\text { Straight to } \\
\text { curved, } \\
\text { commonly } \\
\text { embayed }\end{array}$ & $2 \mathrm{~mm}$ & $\begin{array}{c}\delta^{18} \mathrm{O}:-4.60--7.00 \% \\
\delta^{13} \mathrm{C}: 2.74-4.20 \%\end{array}$ \\
\hline Tempi & $\begin{array}{l}\text { Tmp 1a } \\
\text { Tmp 1b } \\
\text { Tmp 2a } \\
\text { Tmp 2a } \\
\text { Tmp 3a } \\
\text { Tmp 3a }\end{array}$ & $\begin{array}{c}\text { Middle- to } \\
\text { coarse-grained. } \\
\text { Grayish to } \\
\text { white colour }\end{array}$ & calcite & $\begin{array}{l}\text { Homeoblastic } \\
\text { and in some } \\
\text { cases heterob- } \\
\text { lastic. Elon- } \\
\text { gated crystals }\end{array}$ & $\begin{array}{l}\text { Sutured } \\
\text { dentate, } \\
\text { embayed }\end{array}$ & $5 \mathrm{~mm}$ & $\begin{array}{c}\delta^{18} \mathrm{O}:-1.10--6.00 \% \\
\delta^{13} \mathrm{C}: 1.10-3.20 \%\end{array}$ \\
\hline $\begin{array}{l}\text { Chasan- } \\
\text { bali }\end{array}$ & $\begin{array}{l}\text { Chas } 43 \\
\text { Chas } 46\end{array}$ & $\begin{array}{l}\text { Fine-grained. } \\
\text { White colour }\end{array}$ & $\begin{array}{l}\text { calcite, } \\
\text { quartz }\end{array}$ & Homeoblastic & $\begin{array}{c}\text { Straight or } \\
\text { curved }\end{array}$ & $0.5 \mathrm{~mm}$ & $\begin{array}{c}\delta^{18} \mathrm{O}:-4.15--5.60 \% \\
\delta^{13} \mathrm{C}: 2.74-2.94 \%\end{array}$ \\
\hline \multirow{3}{*}{$\begin{array}{l}\text { Tisaion } \\
\text { Mount }\end{array}$} & Triker 1 & $\begin{array}{c}\text { Very fine- } \\
\text { grained. White } \\
\text { colour with pink- } \\
\text { ish tint }\end{array}$ & $\begin{array}{c}\text { calcite, } \\
\text { sulfides, } \\
\text { Fe-oxides }\end{array}$ & Homeoblastic & $\begin{array}{c}\text { Straight to } \\
\text { curved }\end{array}$ & $100 \mu \mathrm{m}$ & $\begin{array}{c}\delta^{18} \mathrm{O}:-1.79 \\
\delta^{13} \mathrm{C}: 3.16 \%\end{array}$ \\
\hline & Triker 2 & $\begin{array}{l}\text { Fine-grained. } \\
\text { White to grayish } \\
\text { white colour } \\
\text { Dark coloured } \\
\text { stripes }\end{array}$ & $\begin{array}{l}\text { calcite, } \\
\text { sulfides, } \\
\text { Fe-oxides }\end{array}$ & Homeoblastic & $\begin{array}{c}\text { Straight to } \\
\text { curved }\end{array}$ & $100 \mu \mathrm{m}$ & $\begin{array}{l}\delta^{18} \mathrm{O}:-3.90 \% \\
\delta^{13} \mathrm{C}: 4.13 \%\end{array}$ \\
\hline & Triker 3 & $\begin{array}{c}\text { Fine-grained. } \\
\text { White to grayish } \\
\text { white colour }\end{array}$ & calcite & Homeoblastic & $\begin{array}{c}\text { Straight to } \\
\text { curved }\end{array}$ & $100 \mu \mathrm{m}$ & $\begin{array}{l}\delta^{18} \mathrm{O}:-0.45 \% \\
\delta^{13} \mathrm{C}: 2.98 \%\end{array}$ \\
\hline
\end{tabular}

*MGS: Maximum grain size of calcites. 

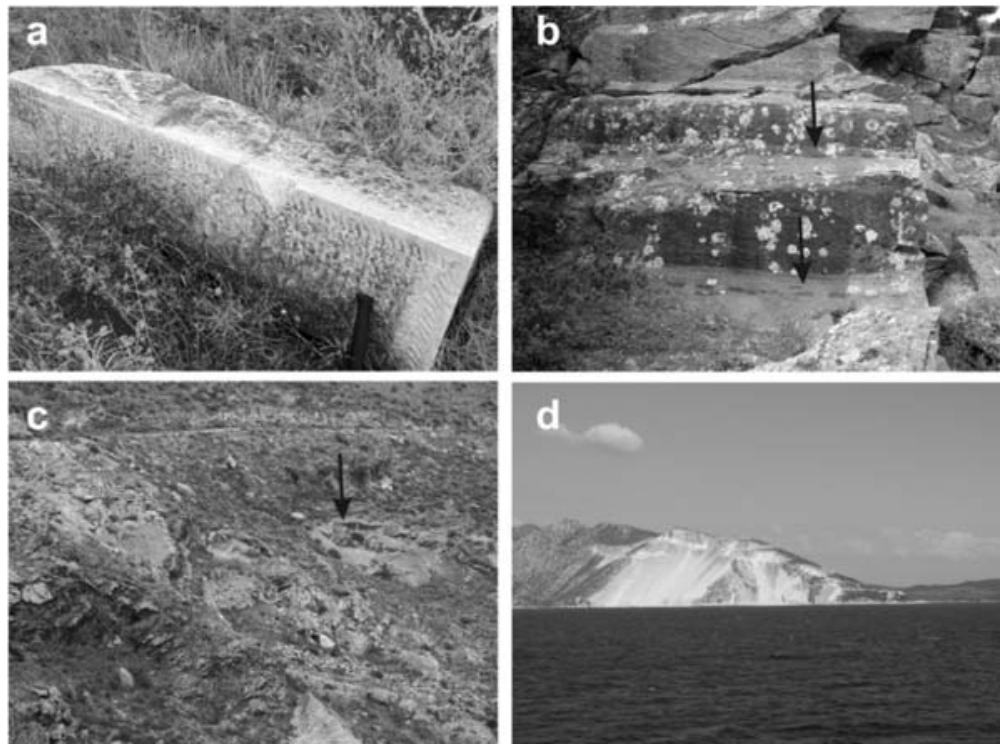

Fig. 2: (a) Unfinished marble block left in the area of the ancient Atrax quarries. (b) Rock faces of an ancient marble quarry in Tempi. The tool traces on the marble and the cavities for the wedges are still preserved. (c) The small ancient white marble quarry in the Chasanbali area. (d) The modern marble quarries at the Tisaion mountain, viewed from the entrance of the Pagasitikos gulf. The extraction works have destroyed all the ancient quarries.

\section{Ancient marble quarries: mineralogical, petrographic and isotopic features}

\subsection{Ancient Atrax}

The marble quarries are located near the ancient city of Atrax, on the NE foot of Titanos mountain (Papageorgakis, 1967; Germann et al., 1980; Karagiorgou 2001). The hollows remained after the removal of the stones as well as the numerous unfinished blocks left in the broader area (Fig. 2a), demonstrate an intense quarrying process during antiquity. These quarries produced two types of marble: a coarse-grained marble with a white to greyish-white colour and a fine-grained white marble with a pinkish tint. According to Karagiorgou (2001), the first type was of high quality and was extensively used in Thessaly for constructing mainly grave stelai and a few sculptures.

The marble of Atrax consists mainly of calcite with traces of apatite, sulphides and Fe-oxides. The texture of the coarse-grained white to greyish-white marble is homeoblastic (Fig. 3a) to slightly heteroblastic, indicating that it is made of equidimensional grains and only rarely it may contain calcite crystals with different sizes. The shape of the boarders of the grains is sutured to dentate and only rarely the boarders are curved. The calcite crystals are commonly embayed. The marble consists of twinned calcite crystals of 0.5 to $2.5 \mathrm{~mm}$ in diameter which rarely reaches up to $4 \mathrm{~mm}$ (MGS). It is a well recrystallized marble resulting in triple-grain junctions of the calcite crystals meeting at about $120^{\circ}$ angles.

The fine-grained white marble with a pinkish tint exhibits a heteroblastic texture with very small grains up to $10 \mu \mathrm{m}$ in diameter, coexisting with larger crystals with a diameter reaching $2 \mathrm{~mm}$. This coarse-grained calcite sometimes is found in the form of veinlets crosscutting the fine-grained crystals. The boarders of the grains are straight to curved and sometimes embayed.

The isotopic results of 3 fresh marble samples collected from the quarry sites are listed in Table 1 

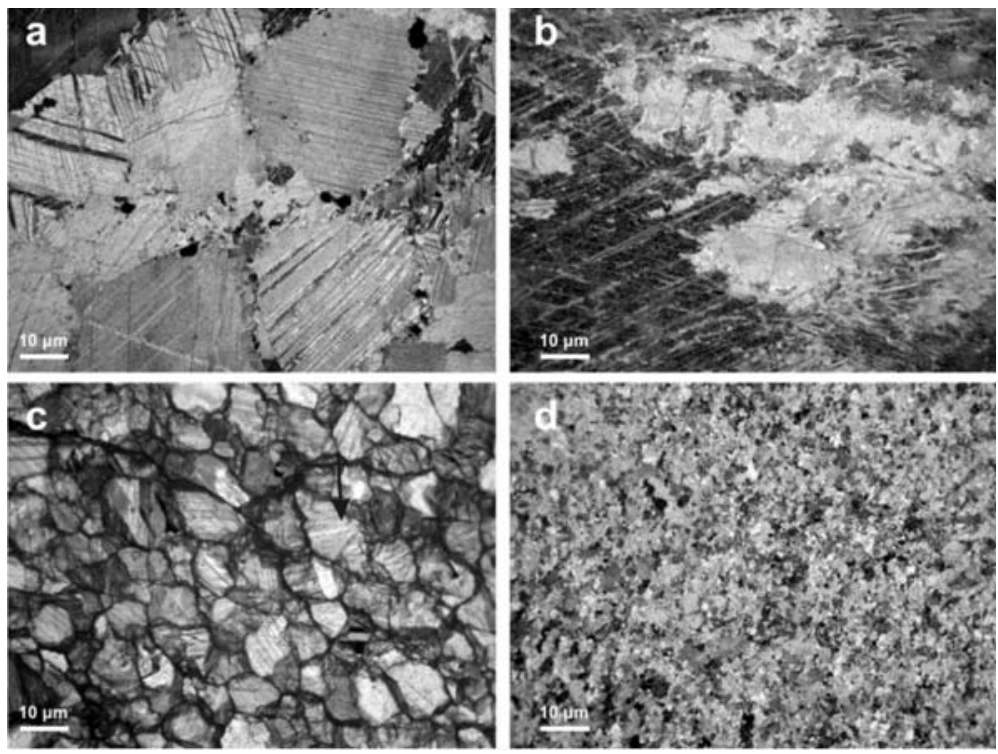

Fig. 3: Photomicrographs $(+\mathrm{N})$ of calcite crystals of the studied marbles showing textural features. (a) Homeoblastic texture of the coarse-grained marble from Atrax (sample Atr1). (b) Marble showing sutured grain boundaries of calcite from Tempi (sample Tmplb). (c) Homeoblastic texture showing triple junction at $120^{\circ}$, from Chasanbali (sample Chas43). (d) Homeoblastic texture of the very fine-grained marble from Tisaion mount (sample Tis1).

and are plotted in the diagram of figure 4. Seven additional isotopic values for marbles of Atrax are from Germann et al. (1980) and two from Capedri et al. (2004). The C-O isotopes of the Atrax marble are not homogeneous and are plotted in two groups demonstrating the two marble types. The $\delta^{13} \mathrm{C}$ values range from +1.65 to $+2.27 \%$ and from +2.74 to $+4.20 \%$. The $\delta^{18} \mathrm{O}$ vary from -1.77 to $-3.36 \%$ o and from -4.60 to $-7.00 \%$.

\subsection{Tempi area}

Three big ancient marble quarries are located on the $\mathrm{N}$ foots the mountain Kissavos, in the middle of the Tempi valley, at a height around $200 \mathrm{~m}$ from the Pineios river, which flows through the valley towards the Aegean sea.

The marbles were quarried from the open pits, the straight rock faces of which rise to a height of up to $5 \mathrm{~m}$ above ground level. The extraction proceeded by step, with at least four levels. Tool traces, especially marks of pickaxes, on the rock and the hollows left behind show the extraction methods and techniques (Fig. 2b). These techniques were simple and were influenced by the geological and structural features of the rock, such as fissures and cracks. The stone was quarried in large massive slabs and monoliths, up to $5 \mathrm{~m}$ in length, up to $3 \mathrm{~m}$ in width, and from 0.70 to $1.10 \mathrm{~m}$ in thickness. The quarrymen cut a bench of the length and the width required for the blocks and they disengaged the blocks from the rock mass by digging a channel $25 \mathrm{~cm}$ wide around the rock slab. Then they chiselled small cavities at the bottom of the blocks, $10 \mathrm{~cm}$ long and $5 \mathrm{~cm}$ wide. After that, they put iron wedges in the cavities and by hammering them they split off the rock slab. The technique used in the Tempi marble quarries was similar with this used elsewhere in Thessaly (Kastri, Gonnoi) and generally in ancient Greece. 
The material which was extracted from the quarries in Tempi was roughly worked by sculpturing in the quarry area. The quarrymen gave an approximate shape to the block for an easier transportation. This suggestion is supported by the observed heaps of waste material and debris, spread around the working area, as well as by the presence of broken columns, up to $2 \mathrm{~m}$ long, left in the quarry.

The marble of Tempi consists only of middle- to coarse-grained calcite crystals. Its colour is from greyish white to grey. The texture is homeoblastic, indicating that it contains equidimensional grains, and only rarely it is heteroblastic. The shape of the boarders of the grains is sutured to dentate (Fig. $3 b$ ). The calcite crystals are commonly embayed. The marble consists of anhedral calcite crystals of up to $5 \mathrm{~mm}$ (MGS) in diameter, and is characterized by a high degree of preferred orientation. The calcite crystals are flattened and elongated parallel to the foliation plane. In cases marble exhibits a heteroblastic texture with the large calcite grains $(>1 \mathrm{~mm})$ intergrowning with smaller grains $(10-100 \mu \mathrm{m})$.

The isotopic results of 6 fresh marble samples collected from the quarry sites are listed in Table 1 and are plotted in the diagram of figure 4. Eight additional isotopic values for marbles of Tempi are from Germann et al. (1980). The $\mathrm{C}-\mathrm{O}$ isotopes are cohesive with $\delta^{13} \mathrm{C}$ values ranging from +1.10 to $+3.20 \%$ and $\delta^{18} \mathrm{O}$ from -1.10 to $-6.00 \%$ o.

\subsection{Chasanbali area}

The Chasanbali area, $12 \mathrm{~km}$ northeast of Larisa, is one of the most significant ancient quarrying sites to international cultural heritage. The quarries provided the "green Thessalian stone" which is an ophicalcite comprising a mosaic of green serpentinite and white marble fragments. This stone was used for decorative purposes in Imperial Rome and especially in Byzantium. Sarcophagi, column shafts, facing slabs, tubs, ambones, iconostaseis and baptismal fonts are still found in places stretching from Syria to Britain and from Tunisia to Germany, as well as Rome, Constantinople and Thessaloniki (Melfos, 2008). Besides the "green Thessalian stone" quarries, on the Chasanbali Hill there is also a small white marble quarry (Fig. 2c) at the easternmost border of the site.

The marble in this quarry comprises a slab in the ophicalcite, $50 \mathrm{~m}$ long and $7 \mathrm{~m}$ thick, and it is an olistolith which was found intercalated among the ophicalcite breccia during Mesozoic (Melfos et al., 2009). It is a fine-grained white coloured marble and consists mainly of calcite with traces of quartz. It has a homeoblastic texture, with equidimensional grains (Fig. 3c). The rims of the grains have straight to curved boarders. The calcite crystals are commonly twinned with a diameter from 100 to $500 \mu \mathrm{m}$ (MGS). Triple-grain junctions of the calcite crystals, at about $120^{\circ}$ angles, is a common feature and demonstrates a well recrystallized marble.

Four samples were collected from the Chasanbali ancient white marble quarry for carbon and oxygen isotopic analyses. The $\delta^{13} \mathrm{C}$ values range from +2.74 to $+2.94 \%$ and the $\delta^{18} \mathrm{O}$ from -4.15 to $5.60 \%$ (Tab. 1, Fig. 4).

\subsection{Tisaion mountain}

A large quarrying area is located at the $\mathrm{N}$ foot of the Tisaion mountain, near the site of Zasteni on the east coast of the Pagasitikos gulf, in Magnesia (Fig. 2d). The quarries extend all along the Tisaion mountain and up to $100 \mathrm{~m}$ above the sea level. According to Papageorgakis (1963), there were two large ancient quarries at some distance from the coast and numerous smaller ones, hidden behind thick vegetation and for this reason inaccessible. Modern exploitation works, in the last decades, have recently destroyed all these ancient quarries, obliterating crucial evidence of their existence. Only a few ancient marble blocks, with marks of pointed chisels, still exist today, being witnesses of the intense quarrying works in antiquity. 


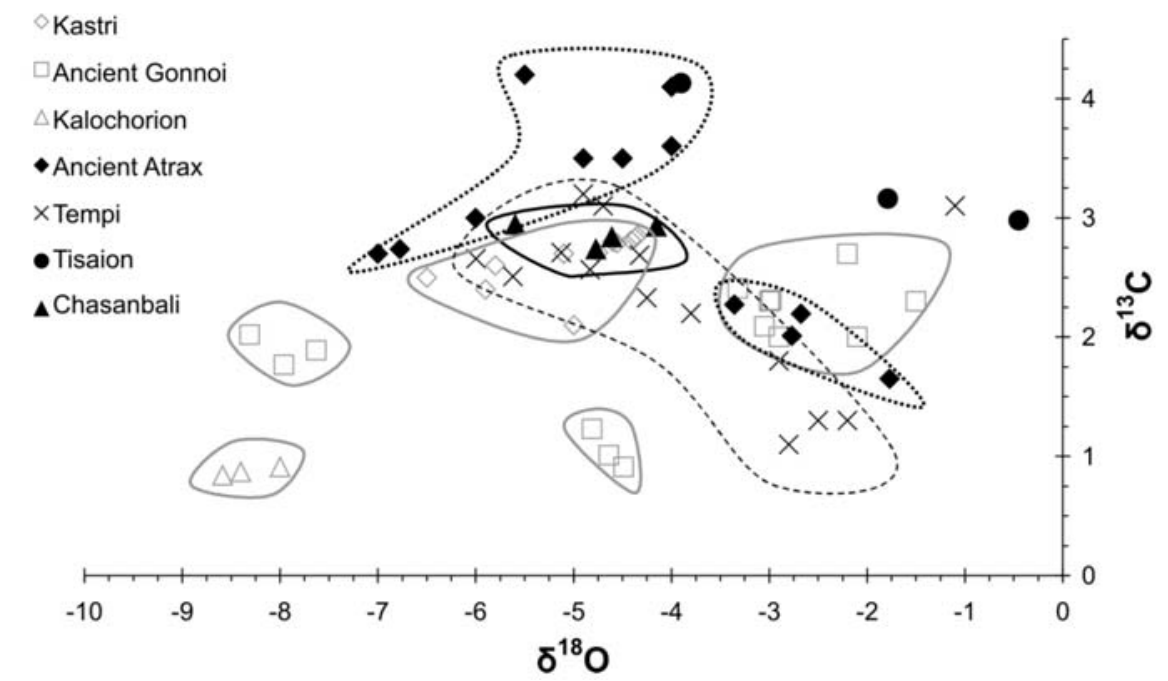

Fig. 4: $\mathrm{A} \delta^{18} \mathrm{O}-\delta^{13} \mathrm{C}$ diagram summarizing the stable isotope data of the marbles from the ancient quarries in Thessaly studied here (Atrax, Tempi, Ghasanbali, Tisaion) in combination with the results of Kastri, Kalochorion and Gonnoi, published by Melfos (2004) (data also from Germann et al. 1980, Melfos et al. 2002, Capedri et al. 2004).

The marble in the Tisaion mountain has a white to greyish white colour. This type is called "Lafkos White" today. Sometimes dark coloured stripes exist parallel to the schistosity. Near the sea, at the lower parts, the marble has a characteristic pinkish tint, and so the trade mark of this type of marble is "Lafkos Pink".

The mineralogical composition of the pinkish- and the greyish-white marble is calcite with traces of dolomite, quartz and Fe-oxides. Calcite is the only constituent of the white marble. The texture of all the types is homeoblastic (Fig. 3d), indicating that it is made of equidimensional grains. The boarders of the grains have straight to curved boarders. The marble is characterized as a fine-grained marble, with grain size varying from $<10 \mu \mathrm{m}$ to $100 \mu \mathrm{m}$. Only rarely there are calcite crystals with a diameter up to $1 \mathrm{~mm}$ (MGS).

Three samples, one of each type, were analyzed for carbon and oxygen isotopes. The results are not homogeneous and so they do not plot as a group (Tab. 1, Fig. 4). The $\delta^{13} \mathrm{C}$ values range from +2.98 to $+4.13 \%$ and the $\delta^{18} \mathrm{O}$ from -0.45 to $-4.13 \%$. More isotopic analyses are planned for the near future in order to better establish the isotopic signatures of the three marble types at the Tisaion mountain.

\section{Discussion-Conclusions}

The present study contributes significantly in the updating of the databases of the marbles from Thessaly, used in antiquity. Petrographic and O-C isotopic results presented here, complete the databases published in previous works for ancient quarries from Kastri, Kalochorion and Gonnoi. The mineralogical and petrographic features of the marble coming from four different localities of Thessaly, e.g. Atrax, Tempi, Chasanbali and Tisaion mountain, show distinct differences and with the combination of the isotopic results may be used to identify the provenance of archaeological marbles. Recently this complete reference data was used successfully in identifying the provenance of the marbles used in the construction of the Ancient Theatre A' of Larisa (Melfos- 
unpublished data) and it is a potential tool in analogous future works from ancient monuments from Thessaly.

According to their stable isotope compositions (Tab. 1), most of the samples plot within the same area, although some groupings are observed (Fig. 4). Globally, $\delta^{18} \mathrm{O}$ values in marine carbonates range from $-10 \%$ to $+5 \%$, but most marine carbonate sediments and limestones are in the range of $-10 \%$ to $+2 \%$ (Nelson and Smith 1996). The values of the marbles from this study vary from $-7.0 \%$ o to $-0.45 \%$ and fall inside this range. More specific the oxygen isotopes can be compared with the isotopes of the Mesozoic marine limestones which range from -7 to $0 \%$ (Veizer et al. 1999), suggesting that they were relatively affected by very low grade metamorphism, which resulted in the recrystallization of the carbonates without any affect in the O-isotopes.

The carbon isotope values of the studied marbles $(+1.10$ to $+4.20 \%$ ) demonstrate a relatively narrow range, which probably shows that the $\mathrm{C}$ source was rather homogeneous for the carbonates which were incorporated within all the marble occurrences. These values represent seawater composition during carbonate deposition and are comparable to values of the non-metamorphic Mesozoic pelagic limestones worldwide which have $\delta^{13} \mathrm{C}$ values mainly from 0 to $3 \%$ (Veizer et al. 1999). This reveals that the marbles preserved their protolith carbon isotope ratios, although the subsequent metamorphic event of low grade caused a recrystallization to most of them, mainly from Atrax and Tempi.

\section{References}

Anders, B., Reischmann, T., and Kostopoulos, D., 2007. Zircon geochronology of basement rocks from the Pelagonian Zone, Greece: constraints on the pre-Alpine evolution of the westernmost Internal Hellenides, Int. J. Earth Sci., 96, 639-661.

Attanasio, D., De Marinis, G., Pallecchi, P., Platania, R., and Rocchi, P., 2003. An EPR and isotopic study of the marbles of the Trajan's Arch at Ancona: An example of alleged Hymettian provenance, Archaeometry, 45, 553-568.

Capedri, S., Giampiero, V., and Photiades, A., 2004. Accessory minerals and $\delta^{18} \mathrm{O}$ and $\delta^{13} \mathrm{C}$ marbles from Mediterranean area, Journal of Cultural Heritage, 5, 27-47.

Caputo, R., 1990. Geological and structural study of the recent and active brittle deformation of the Neogene-Quaternary basins of Thessaly (Central Greece), $\mathrm{PhD}$ Thesis, Aristotle University of Thessaloniki, 251pp.

Coleman, M., and Walker, S., 1979. Stable isotope identification of Greek and Turkish marbles. Archaeometry, 21, 107-112.

Craig, H., and Craig, V., 1972. Greek marbles: Determination of provenance by isotopic analyses, Science, $176,401-403$.

Danelian, T., and Robertson, A.H.F., 2001. Neotethyan evolution of eastern Greece (Pagondas Mélange, Evia island) inferred from radiolarian biostratigraphy and the geochemistry of associated extrusive rocks, Geological Magazine, 138, 345-363.

Germann K., Holzmann, G., and Winkler F.J., 1980. Determination of marble provenance: Limits of isotopic analyses, Archaeometry, 22, 99-106.

Gorgoni, C., Lazzarini, L., Pallante, P., Turi, B., 2002. An updated and detailed mineropetrographic and C-O stable isotopic reference database for the main Mediterranean marbles used in antiquity. In J.J. Herrmann Jr., N. Herz, and R. Newman (eds), Interdisciplinary Studies on Ancient Stone. Archetype Publ., London, 115-131.

Herz, N., 1987. Carbon and oxygen isotopic ratios: A data base for classical Greek and Roman marble, 
Archaeometry, 29, 35-43.

Karagiorgou, O., 2001. Urbanism and Economy in Late Antique Thessaly (3rd - 7th c. A.D.): the archaeological evidence, $\mathrm{PhD}$ Thesis, University of Oxford, 254pp.

Katsikatsos, G., Vidakis, M., and Migiros, G., 1981. Platycampos sheet, Geological map of Greece, 1:50,000, IGME, Athens.

Kilias A., and Mountrakis D., 1989. The Pelagonian nappe. Tectonics, metamorphism and magmatism, Bulletin of the Geological Society of Greece, XXIII/1, 29-46.

Koroneos, A., Christofides, G., Del Moro, A., and Kilias, A., 1993. Rb-Sr geochronology and geochemical aspects of the Eastern Varnountas plutonite (NW Macedonia, Greece), Neues Jahrbuch für Mineralogie, Abhandlungen, 165, 297-315.

Lazzarini, L., 2004. Archaeometric aspects of white and coloured marbles used in antiquity, the state of the art. In G.M. Bargossi, M. Franzini and B. Messiga (eds) A showcase of the Italian research in Applied Petrology, Special Issue 3, Periodico di Mineralogia, 73, 113-125.

Lazzarini, L., Moschini, G., and Stievano, B.M., 1980. A contribution to the identification of Italian, Greek and Anatolian marbles through a petrological study and the evaluation of $\mathrm{Ca} / \mathrm{Sr}$ ratio, $\mathrm{Ar}$ chaeometry, 22,173-183.

Melfos, V., 2004. Mineralogical and stable isotopic study of ancient white marble quarries in Larissa, Thessaly, Greece, Bulletin of the Geological Society of Greece, XXXVI/3, 1164-1172.

Melfos, V., 2008. "Green Thessalian Stone": The Byzantine quarries and the use of a unique architecture material from Larisa area, Greece. Petrographic and geochemical characterization, Oxford Journal of Archaeology, 27, 387-405.

Melfos V., Magganas A., Voudouris P. and Kati M. (2009). The Mesozoic Larissa ophicalcite-serpentinite association in Eastern Thessaly, Greece: Mineralogical, geochemical and isotopic constraints for rocks formed in an Ocean-Continent Transition setting. Geophysical Research Abstracts, EGU General Assembly 2009, vol. 11, EGU2009-10797-2.

Melfos, V., Vavelidis, M., and Theodorikas, S., 2002. Preservation of the Greek Cultural Heritage: A study of the geology and extraction techniques of two ancient quarries, Larisa prefecture, Thessaly, Greece. In A. Kungolos et al. (eds), Proceedings of the International Conference "Protection and Restoration of the Environment VI", 1535-1544.

Mello, E., Monna, D., and Oddone, M., 1988. Discriminating sources of Mediterranean marbles: a pattern recognition approach, Archaeometry, 30, 102-108.

Moens, L., Roos, P., De Rudder, J., Hoste, J., De Paepe, P., Van Hende, J., Marechal, R., and Waelkens M., 1988. White marble from Italy and Turkey: An archaeometric study based on minor-and traceelement analysis and petrography, Journal of Radioanalytical and Nuclear Chemistry, 123, 333-348.

Nelson, C.S., and Smith, A.M. 1996. Stable oxygen and carbon isotope compositional fields for skeletal and diagenetic components in New Zealand Cenozoic non-tropical carbonate sediments and limestones: A synthesis and review. New Zealand Journal of Geology and Geophysics, 39, 93-107.

Papageorgakis, I., 1963. Contribution to the knowledge on the utilization of marbles in ancient Greece and their quarries. 1. The ancient quarries of Thessaly, Proceedings of the Academy of Athens, 38, 564572 (in greek).

Papageorgakis, I., 1967. The stones used in the "Marble industry" of Greece, Analles Geologiques Des Pays Helleniques, 18, 193-270 (in greek).

Perugini, D., Poli, G., Moroni, B., and Turi, B., 2004. A Novel Approach Integrating Image Analysis, Fractal Geometry and Stable Isotope Geochemistry for Provenance Determination of Marbles. In A. Chatzipetros and S. Pavlides (eds), Proceedings of the 5th International Symposium on Eastern 
Mediterranean Geology, Thessaloniki, Greece, 776-779.

Pomonis, P., Tsikouras, B., and Hatzipanagiotou, K., 2007. Petrogenetic evolution of the Koziakas ophiolite complex (W. Thessaly, Greece), Mineralogy and Petrology, 89, 77-111

Robertson, A.H.F., Clift, P.D., Degnan, P.J., and Jones G., 1991. Palaeogeographic and palaeotectonic evolution of the Eastern Mediterranean Neotethys, Palaeogeography, Palaeoclimatology, Palaeoecology, 87, 289-343.

Tsirambides, A., 1996. Provenance determination of Greek white marbles by isotopic analysis of oxygen and carbon. In Proceedings of the 2nd Symposium of the Hellenic Archaeometrical Society, Thessaloniki, 385-394.

Tycot, P.H., 2004. Scientific methods and applications to archaeological provenance studies. In M. Martini, M. Milazzo and M. Piacentini (eds) Proceedings of the International School of Physics "Enrico Fermi" Course CLIV, IOS Press, Amsterdam, 407-432.

Vakoulis, Th., 2000. Marble quarries in ancient Macedonia and investigation of provenance for the marble,. Ph.D. Thesis, Aristotle University of Thessaloniki, 256pp.

Veizer, J., Ala, D., Azmy, K., Bruckschen, P., Buhl, D., Bruhn, F., Carden, G.A.F., Diener, A., Ebneth, S., Godderis, Y., Jasper, T., Korte, Ch., Pawellek, F., Podlaha, O., Strauss, H. 1999. 87Sr/86Sr, $\delta^{13} \mathrm{C}$ and $\delta^{18} \mathrm{O}$ evolution of Phanerozoic seawater, Chemical Geology, 161, 59-88. 